\title{
Effect of Body Mass Index and Fat Mass Measured Using a Tanita Body-fat Analyser on Caecal Intubation Time: A Prospective Clinical Study
}

\section{Tanita Vücut Yağ Analizörü Kullanılarak Ölçülen Vücut Kitle İndeksi ve Fat Mass'ın Çekal Entübasyon Süresi Üzerindeki Etkisi: Prospektif Klinik Çalışma}

\author{
(1) Ufuk Arslan \\ Bursa Yüksek İhtisas Training and Research Hospital, Clinic of General Surgery, Bursa, Turkey
}

\section{IIIIIIIII ABSTRACT}

Aim: Factors such as the endoscopist's experience, bowel preparation and past abdominal surgery all affect caecal intubation time (CIT) in colonoscopy procedures. The present study investigated the effects of body mass index (BMI) and fat mass on CIT.

Method: The data of 110 patients who underwent colonoscopy and CIT measurement that was performed by a single endoscopist as part of colorectal cancer screening in our clinic between February 2020 and March 2020 were prospectively reviewed. The demographic data of the patients were recorded, along with any history of abdominal surgery, use of additional manoeuvers, BMI, fat mass measurements and CITs. The fat mass and BMI values were measured using a Tanita body-fat analyser device. The results were compared using statistical methods.

Results: CIT was found to be lower in females than in males $(\mathrm{p}<0.001)$. In addition, it was longer in patients with a history of abdominal surgery and in those who required additional manoeuvers during the colonoscopy $(\mathrm{p}=0.027)(\mathrm{p}<0.001)$. No statistically significant relationship was found between BMI and CIT ( $\mathrm{p}=0.199$ ). In an evaluation of all the patients, a significant relationship was found between fat mass and CIT ( $\mathrm{p}=0.034$ ).

Conclusion: CIT decreases with increasing total body fat mass, regardless of the BMI. Our findings suggest that fat mass has a greater influence than BMI on CIT for a colonoscopy.

Keywords: Body mass index, caecal intubation time, fat mass, colonoscopy

\section{|||||||||| ÖZ}

Amaç: Kolonoskopi uygulamasında çekum entübasyon süresine (CIT) endoskopistin deneyimi, barsak hazırlı̆̆ı ve geçirilmiş abdominal operasyonlar gibi faktörler etki etmektedir. Bu çalışmanın amacı vücut kitle indeksi (VKi) ve fat massın CIT’ye etkisini araştırmaktır.

Yöntem: Şubat 2020-Mart 2020 arasında kliniğimizde kolorektal kanser taraması amacıyla tek endoskopist tarafından kolonoskopi yapılan ve CIT ölçülen 110 hastanın verileri prospektif olarak kaydedildi. Hastaların demografik verileri kaydedildi, geçirilmiş abdominal cerrahi, ek manevra kullanımı, VKI ve fat mass ölçüm değerleri ve CIT değerlendirildi. Fat mass ve VKİ değerleri Tanita vücut yağ analizörü cihazı ile ölçüldü. Sonuçlar istatistiksel olarak karşılaştırıldı.

Bulgular: CIT kadınlarda daha kısa bulundu ( $\mathrm{p}<0,001)$. Geçirilmiş abdominal cerrahisi olan ve kolonoskopi sırasında ek manevra kullanılan hastalarda CIT daha uzun bulundu ( $\mathrm{p}=0,027)(\mathrm{p}<0,001)$. VKİ ile CIT arasında istatistiksel anlamlı fark bulunmadı ( $\mathrm{p}=0,199)$. Hastaların tümü incelendiğinde fat mass ile CIT arasında istatistiksel anlamlı fark bulundu $(\mathrm{p}=0,034)$.

Sonuç: VKI'den bağımsız olarak total vücut fat mass değeri arttıkça CIT kısalmaktadır. Kolonoskopi sırasında CI süresine fat mass'ın, VKI'den daha fazla etkisinin olduğunu düşünüyoruz.

Anahtar Kelimeler: Vücut kitle indeksi, çekum entübasyon süresi, fat mass, kolonoskopi

Address for Correspondence/Yazışma Adresi: Ufuk Arslan MD,

Bursa Yüksek İhtisas Training and Research Hospital, Clinic of General Surgery, Bursa, Turkey

E-mail: drufuk33@hotmail.com ORCID ID: orcid.org/0000-0002-3050-167X

Received/Geliş Tarihi: 05.04.2020 Accepted/Kabul Tarihi: 24.04.2020

${ }^{\oplus}$ Copyright 2020 by Turkish Society of Colon and Rectal Surgery

Turkish Journal of Colorectal Disease published by Galenos Publishing House. 


\section{Introduction}

Colonoscopy is an effective and important procedure used in the diagnosis and treatment of colorectal diseases. ${ }^{1,2}$ Caecal intubation is the most important parameter when evaluating the success of a colonoscopy procedure, and it is essential for a comprehensive examination of the colon. ${ }^{2}$ Caecal intubation time (CIT) is defined as the time needed to reach the caecum after inserting the endoscope into the anal canal. ${ }^{3}$ Caecal intubation is considered complete with the ileocaecal valve and appendiceal orifice are visualised. ${ }^{4} \mathrm{~A}$ prolonged CIT indicates difficulty in performing a complete colonoscopy. ${ }^{5}$

Many factors affect the CIT in colonoscopy, the most important of which are age, sex, history of abdominal surgery, insufficient bowel preparation, experience of the endoscopist, body mass index (BMI) and visceral fat tissue. ${ }^{6,7}$ It is important to recognise these factors, as they may guide the operator in identifying patients who are prone to a prolonged colonoscopy time, thus aiding in selecting the appropriate sedation and analgesia for the procedure. ${ }^{3}$

A low waist circumference and visceral fat mass are known to prolong the colonoscopy duration. ${ }^{8}$ Additionally, prolonged procedural time is seen in the presence of insufficient bowel preparation and the use of additional manoeuvers in patients with high BMIs. ${ }^{8}$

There is limited available data regarding the relationship between CIT, fat mass and BMI during colonoscopy. This prospective study aimed to evaluate the effect of fat mass and BMI on CIT.

\section{Material and Methods}

The data of 110 patients who underwent colonoscopy for colorectal cancer screening in our hospital between February 2020 and March 2020, and whose CIT was determined during colonoscopy, were prospectively reviewed. Detailed information about the study was provided to the patients, and their written informed consent was obtained. The study was conducted in accordance with the principles of the Helsinki Declaration, and was approved by the local ethics committee (number: 2011-KAEK-25 2020/02-07).

The study included outpatients aged between 18-80 years. In line with the World Health Organisation, patients were divided into two groups: younger than 65 and older than 65 years. Patients whose colonoscopy procedure could not be continued due to insufficient bowel preparation, those who did not give their informed consent and those with colonic polyps, diverticula, tumours or history of colon surgery, were excluded from the study.

The time taken to pass from the start of the anal canal to complete caecal intubation with visualisation of the ileocecal valve and the appendiceal orifice was determined for each patient in the endoscopy unit. The BMI and fat mass of each patient were measured before the procedure, using a Tanita body-fat analyser device. Colonoscopies were performed in a single centre, by the same endoscopist. For bowel preparation, all the patients were placed on a lowfibre diet for two days prior to the procedure and ingested a polyethylene glycol solution (Golytely ${ }^{\circledR}$ ) in divided doses before the procedure. All the colonoscopy interventions were performed in the endoscopy unit under sedoanalgesia.

\section{Statistical Analysis}

Demographic data of the patients, previous non-colonic surgeries, the use of additional manoeuvers during the procedure, CIT, BMI and fat mass were recorded and evaluated.

The normal distribution of the CIT results was verified with a Shapiro-Wilk test and median CIT values were reported (interquartile range). Mann-Whitney $\mathrm{U}$ and KruskalWallis tests were used to compare the CIT measurements between the groups. The relationships between CIT, age and fat mass were analysed using a correlation analysis, and the Spearman's correlation coefficient was calculated. The statistical analysis was carried out using the Statistical Package for Social Sciences (SPSS IBM Corp. Released 2012. IBM SPSS Statistics for Windows, Version 21.0. Armonk, NY: IBM Corp.) software, and a p value of less than 0.05 was considered statistically significant.

\section{Results}

The study comprised 110 patients. No complications were recorded during or after the colonoscopy. However, caecal intubation could not be performed in two patients due to a long sigmoid colon and excessive loop formation. Of the patients, $51.8 \%$ were males and $48.2 \%$ were females; $72.7 \%$ of the patients were aged 65 years or younger, with $27.3 \%$ aged older than 65 years. A history of non-colorectal abdominal surgery (hysterectomy, myomectomy, prostatectomy, herniorrhaphy, caesarean section, etc.) was noted in 19\% of the patients. Additional manoeuvers were required during the procedure in $27.3 \%$ of the patients. The patients were divided into four groups according to their BMI (Figure 1). Demographic data of the patients, previous non-colonic surgeries, the need for additional manoeuvers and the relationship between BMI and mean CIT were evaluated (Table 1). It was found that CIT varied according to sex $(\mathrm{p}<0.001)$, with a longer median CIT in males, although there was no significant difference in CIT between the two age groups $(\mathrm{p}=0.460)$. The median CIT was longer in patients with a history of abdominal surgery $(\mathrm{p}=0.027)$, and in patients who required the use of additional manoeuvers 


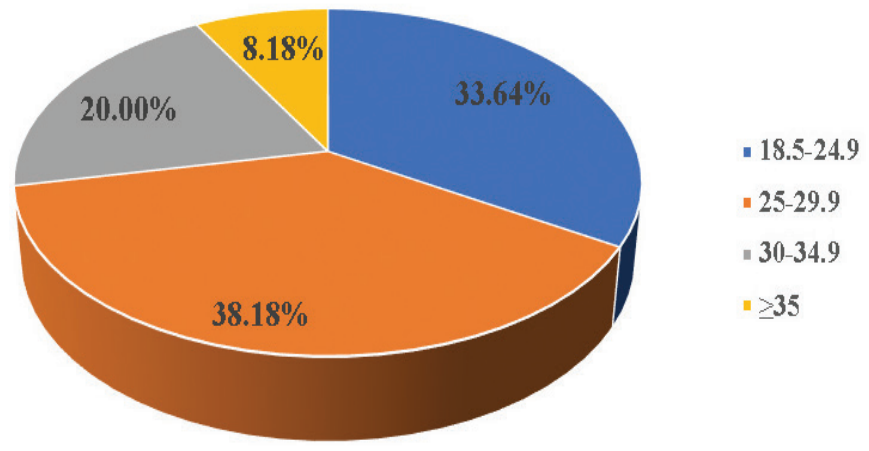

Figure 1. Distribution of BMI among the patients

Table 1. Distribution of the predictors of caecal intubation time (CIT)

\begin{tabular}{llll} 
Variables & $\mathbf{n}(\%)$ & CIT (min) & p value \\
Sex & & & \\
Male & $57(51.82 \%)$ & $9(4)$ & $<0.001^{\mathrm{a}}$ \\
Female & $53(48.18 \%)$ & $7(3)$ & \\
Age (years) & & & \\
$\leq 65$ & $80(72.73 \%)$ & $8(3.75)$ & $0.460^{\mathrm{a}}$ \\
$>65$ & $30(27.27 \%)$ & $8(3.25)$ & \\
Previous surgery & & & \\
Yes & $21(19.09 \%)$ & $9(5.50)$ & $0.027^{\mathrm{a}}$ \\
No & $89(80.91 \%)$ & $8(3)$ & \\
Use of additional manoeuvers & & $<0.001^{\mathrm{a}}$ \\
Yes & $30(27.27 \%)$ & $11(3.50)$ & \\
No & $80(72.73 \%)$ & $8(3)$ & \\
Body mass index & & $8(4)$ & \\
$18.5-24.9$ & $37(33.64 \%)$ & $8(4.50)$ & \\
$25-29.9$ & $42(38.18 \%)$ & $8(4)$ & \\
$30-34.9$ & $22(20 \%)$ & $8(8.18 \%)$ & $799^{\mathrm{b}}$ \\
$\geq 35$ & $9(2)$ & \\
\hline
\end{tabular}

CIT: Caecal intubation time was presented as median (interquartile range)

${ }^{a}$ Mann-Whitney U test, ${ }^{b}$ Kruskal-Wallis test $(\mathrm{p}<0.001)$. The relationship between CIT and BMI was not statistically significant ( $\mathrm{p}=0.199)$.

CIT and the relevant variables were evaluated with a correlation analysis, and the association between fat mass, age and CIT is presented in Table 2. When all of the data were evaluated regardless of sex, no significant relationship was observed between age and CIT $(p=0.21)$, while an inverse relationship was found between fat mass and CIT $(p=0.034)$. In a subgroup analysis of the females, no association between fat mass and CIT was identified, whereas an inverse relationship between age and CIT in females was found $(p=0.047)$. It was therefore concluded that CIT decreases with increasing age in females. There was no relationship between CIT, age and fat mass in males. When the complete patient group was analysed, CIT was found to decrease with increasing fat mass regardless of sex $(\mathrm{p}=0.034)$.

The relationship between CIT and BMI in males and females was evaluated (Table 3). No significant relationship was observed between CIT and BMI in both the male and female groups ( $\mathrm{p}=0.631$ and $\mathrm{p}=0.890)$ (Figure 2$)$.

\section{Discussion}

When investigating the effect of BMI and fat mass on CIT, we need to minimise the number of variables. The most important factor affecting the success of a colonoscopy is the experience of the endoscopist and the procedural

Table 3. Comparison of CIT according to BMI within sex groups

\begin{tabular}{lllll} 
& \multicolumn{2}{c}{ Female $(\mathrm{n}=53)$} & \multicolumn{2}{l}{ Male $(\mathrm{n}=57)$} \\
& $\mathrm{n}$ & CIT & $\mathrm{n}$ & CIT \\
Body mass index & & & & \\
$18.5-24.9$ & 19 & $7(3)$ & 18 & $9(4.25)$ \\
$25-29.9$ & 15 & $8(3)$ & 27 & $9(5)$ \\
$30-34.9$ & 14 & $6(3.25)$ & 8 & $8.50(1.75)$ \\
$\geq 35$ & 5 & $6(1)$ & 4 & $8(5.25)$ \\
p value & $0.631^{\mathrm{b}}$ & & $0.890^{\mathrm{b}}$ &
\end{tabular}

CIT: Caecal intubation time was presented as median (interquartile range)

${ }^{\mathrm{b}}$ Kruskal-Wallis test

Table 2. Relationship between caecal intubation time (CIT) and age and fat mass

\begin{tabular}{lllllll} 
& Female $(\mathrm{n}=53)$ & & Male $(\mathrm{n}=57)$ & & \multicolumn{2}{c}{ Total $(\mathrm{n}=110)$} \\
CIT & $\mathrm{r}_{\mathrm{s}}$ & $\mathrm{p}$ value & $\mathrm{r}_{\mathrm{s}}$ & $\mathrm{p}$ value & $\mathrm{r}_{\mathrm{s}}$ & $\mathrm{p}$ value \\
Fat mass & -0.23 & 0.097 & -0.14 & 0.305 & -0.20 & 0.034 \\
Age & -0.28 & 0.047 & 0.05 & 0.717 & -0.12 & 0.210
\end{tabular}

CIT: Caecal intubation time, $r_{s}$ : Spearman's correlation coefficient 


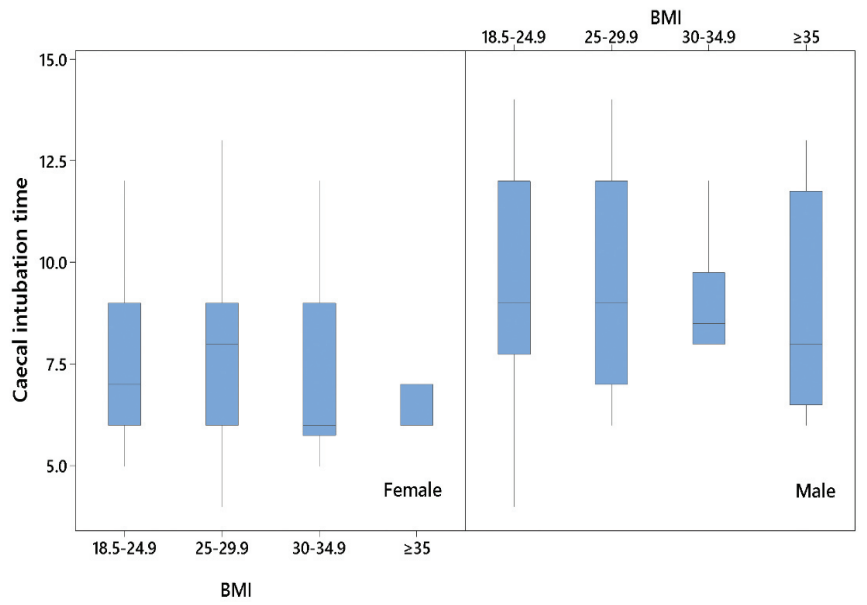

Figure 2. Caecal intubation time by BMI and sex BMI: Body mass index

volume. ${ }^{9,10}$ Thus, all the procedures in the present study were performed by a single endoscopist using the same standard protocol.

Numerous studies in the literature have suggested that sex may be significant in decreasing or increasing the CIT. ${ }^{11,12}$ However, the most important factor affecting this parameter was found to be the sharp difference between the number of male and female patients. In the present study, there was almost no difference in the number of males and females and CIT was found to be longer among males $(\mathrm{p}<0.001)$. Previous studies have also identified a positive relationship between advanced age and CIT, ${ }^{13}$ which has been attributed to the increase in colon length and the decreased colonic elasticity that naturally occurs with age. In our study, caecal intubation could not be performed in two patients due to a long sigmoid colon and excessive loop formation (1.78\%). This rate is consistent with the findings in the literature. ${ }^{14}$ In the overall study population, no significant relationship was found between age and CIT. The authors consider that the difference in the effects of sex and age on CIT can be attributed to the small sample size.

The literature shows that a history of abdominal surgery and intraabdominal adhesions secondary to previous abdominal surgeries can prolong the CIT. ${ }^{15,16}$ The present study found that CIT was prolonged in the case of previous abdominal surgery $(\mathrm{p}=0.027$ ), with hysterectomy, in particular, being found to complicate the colonoscopy. ${ }^{17}$ Another finding of our study was that the use of additional manoeuvers during colonoscopy lengthens the CIT. Changing the position of the sedated patient during the procedure and applying compression to the abdomen to resolve the loops may prolong the CIT. ${ }^{3}$

BMI is commonly used to measure obesity, although it does not take into account the intraabdominal fat mass, does not differentiate between fat and muscle tissue, or provide information about the type of fat deposited. ${ }^{18}$ While computed tomography is undisputedly the optimal approach to the measurement of intraabdominal fat tissue, this is an impractical method to use in large numbers of patients, and has a high cost. ${ }^{7,8}$ The present study therefore evaluated the relationship between BMI, fat mass (measured with a Tanita body-fat analyser) and CIT.

The relationship between the technical difficulties encountered in colonoscopies and body weight has been investigated by many authors. Previous studies have suggested that obesity can either increase or decrease CIT. ${ }^{19,20}$ Difficult colonoscopies and prolonged CIT in obese patients have been linked to insufficient bowel preparation. ${ }^{8}$ Patients with a greater fat mass have loose colonic mesentery due to the presence of excessive visceral fat tissue. This causes the development of further bowel loops and the need to use additional manoeuvers during the procedure. ${ }^{21}$ This may be another reason for the prolonged CIT in patients with high fat mass and BMI.

Conversely, some studies that reported a relationship between visceral fat tissue and CIT suggested that CIT shortens with increasing visceral fat tissue. ${ }^{21,22}$ The present study results show that CIT decreases with an increase in fat mass ( $\mathrm{p}=0.034$ ), a finding that could be attributed to the direct support of the colon that visceral fat provides within the pelvis, which thereby allows for the smooth passage of the colonoscope..$^{22}$ In previous studies, visceral fat tissue was measured using computerised tomography (CT) scans prior to the procedure, a method which is both impractical and expensive, although it can be used for the isolated measurement of the abdominal visceral fat tissue. In the present study, the Tanita body-fat analyser was used due to its low cost and practicality. Furthermore, the method applied in the present study evaluates the total body fat mass ratio rather than the isolated intraabdominal visceral adipose tissue measured by CT scans. Despite this difference, the results of the present study are similar to those reported in the literature.

Prolonged CIT during colonoscopy may lead to consequences such as respiratory depression, hypotension, arrhythmia and aspiration. ${ }^{20}$ For this reason, CIT becomes even more significant in patients with a high fat mass, who carry potential risks.

\section{Conclusion}

In conclusion, the present study shows that fat mass has a greater effect than BMI on CIT. Furthermore, a Tanita bodyfat analyser can be used in place of CT due to its lower cost and practicality, to evaluate the relationship between body 
fat mass and CIT. The present study is the first to evaluate the effect of fat mass measured by a Tanita body-fat analyser on CIT. The authors suggest that prospective multi-centre studies involving larger numbers of patients may provide more valuable data.

\section{Ethics}

Ethics Committee Approval: The study was conducted in accordance with the principles of the Helsinki Declaration, and was approved by the local ethics committee (number: 2011-KAEK-25 2020/02-07).

Informed Consent: Obtained.

Peer-review: Externally peer reviewed.

Financial Disclosure: The authors declared that this study received no financial support.

\section{References}

1. Özsoy M, Celep B, Ersen O, Özkececi T, Bal A, Yılmaz S, Arıkan Y. Our results of lower gastrointestinal endoscopy: evaluation of 700 patients. Ulus Cerrahi Derg 2014;30:71-75.

2. Jia H, Wang L, Luo H, Yao S, Wang X, Zhang L, Huang R, Liu Z, Kang X, Pan Y, Guo X. Difficult colonoscopy score identifies the difficult patients undergoing unsedated. BMC Gastroenterol 2015;15:46.

3. Akere A, Otegbayo JA. Complete colonoscopy: impact of patients' demographics and anthropometry on caecal intubation time. BMJ Open Gastroenterol 2016;7:e000076.

4. Karapolat B, Kucuktulu U. The Relationship between Waist Circumference and Cecal Intubation Time in Women. J Coll Physicians Surg Pak 2018;28:872-874.

5. Anderson JC, Messina CR, Cohn W, Gottfried E, Ingber S, Bernstein G, Coman E, Polito J. Factors predictive of difficult colonoscopy. Gastrointest Endosc 2001;54:558-562.

6. Chung GE, Lim SH, Yang SY, Song JH, Kang HY, Kang SJ, Kim YS, Yim JY, Park MJ. Factors that determine prolonged cecal intubation time during colonoscopy: impact of visceral adipose tissue. Scand J Gastroenterol 2014:49:1261-1267.

7. Nagata N, Sakamoto K, Arai T, Niikura R, Shimbo T, Shinozaki M, Noda M, Uemura N. Predictors for cecal insertion time: the impact of abdominal visceral fat measured by computed tomography. Dis Colon Rectum 2014;57:1213-1219.

8. Jain D, Goyal A, Uribe J. Obesity and cecal intubation time. Clin Endosc 2016;49:187-190.
9. Bernstein C, Thorn M, Monsees K, Spell R, O'Connor JB. A prospective study of factors that determine cecal intubation time at colonoscopy. Gastrointest Endosc 2005;61:72-75.

10. Moon SY, Kim BC, Sohn DK, Han KS, Kim B, Hong CW, Park BJ, Ryu KH, Nam JH. Predictors for difficult cecal insertion in colonoscopy: The impact of obesity indices. World J Gastroenterol 2017;23:2346-2354.

11. Hsieh YH, Kuo CS, Tseng KC, Lin HJ. Factors that predict caecal insertion time during sedated colonoscopy: the role of waist circumference. J Gastroenterol Hepatol 2008;23:215-217.

12. Krishnan P, Sofi AA, Dempsey R, Alaradi O, Nawras A. Body mass index predicts cecal insertion time: the higher, the better. Dig Endosc 2012;24:439-442.

13. Sadahiro S, Ohmura T, Yamada Y, Saito T, Taki Y. Analysis of length and surface area of each segment of the large intestine according to age, sex and physique. Surg Radiol Anat 1992;14:251-257.

14. Tardu A, Türkyılmaz Z, Yılmaz ME, Çelik G. Does propofol sedation increase the cecal intubation rate in colonoscopy? Laparosc Endosc Surg 2017;24:46-49.

15. Park CH, Lee WS, Joo YE, Kim HS, Choi SK, Rew JS, Kim SJ. Sedationfree colonoscopy using an upper endoscope is tolerable and effective in patients with low body mass index: a prospective randomized study. Am J Gastroenterol 2006;101:2504-2510.

16. Hull T, Church JM. Colonoscopy -- how difficult, how painful? Surg Endosc 1994:8:784-787.

17. Chutkan R. Colonoscopy issues related to women. Gastrointest Endosc Clin N Am 2006;16:153-163.

18. Harvard T.H. Boston: Harvard T.H. Chan School of Public Health; c2016. Chan School of Public Health. From calipers to CAT Scans, ten ways to tell whether a body is fat or lean (Internet) (cited Feb 2).

19. Witte TN, Enns R. The difficult colonoscopy. Can J Gastroenterol 2007;21:487-490.

20. Park HJ, Hong JH, Kim HS, Kim BR, Park SY, Jo KW, Kim JW. Predictive factors affecting cecal intubation failure in colonoscopy trainees. BMC Med Educ 2013;13:5.

21. Nagata N, Sakamoto K, Arai T, Niikura R, Shimbo T, Shinozaki M, Noda M, Uemura N. Predictors for cecal insertion time: the impact of abdominal visceral fat measured by computed tomography. Dis Colon Rectum 2014;57:1213-1219.

22. Chung GE, Lim SH, Yang SY, Song JH, Kang HY, Kang SJ, Kim YS, Yim JY, Park MJ. Factors that determine prolonged cecal intubation time during colonoscopy: impact of visceral adipose tissue. Scand J Gastroenterol 2014;49:1261-1267. 